кандидат педагогічних наук, доцент (Східноукраїнський національний університет імені Володимира Даля, м. Сєвєродонецьк) tetyanateacher@gmail.com ORCID: 0000-0002-7345-4586

\title{
ІНТЕРНАЦІОНАЛІЗАЦІЯ ВИЩОЇ ОСВІТИ В КОНТЕКСТІ ВИКЛАДАННЯ АНГЛІЙСЬКОӤ МОВИ ПРОФЕСІЙНОГО СПРЯМУВАННЯ: ДОСВІД ВЕЛИКОБРИТАНІЇ
}

В статті розглянута проблема інтернаціоналізації вищої освіти в контексті викладання англійської мови професійного спрямування. Досліджено позицію експертів Великобританії стосовно перспектив підвищення стандартів викладання англійської мови для професійного спілкування на базі вітчизняних ВН3. Визначено наявні проблеми та потенційні шляхи інтернаціоналізащії вітчизняної вищої школи 8 зазначеному контексті.

Ключові слова: інтернаціоналізація, вища освіта Великобританії, англійська мова професійного спрямування, Загальноєвропейські рекомендації з мовної освіти, міжнародні стандарти викладання та вивчення англійської мови.

Постановка проблеми. Інтеграція вітчизняної системи освіти до Свропейського простору зумовлює потребу вивчення та залучення успішних світових практик в освітній галузі. Особливо важливим це завдання постає перед вищою школою - як фінальною ланкою підготовки конкурентоспроможних фахівців для вітчизняного та міжнародного ринків праці. У зазначеному контексті відіграє ключову роль англійська мова як інструмент професійного спілкування. Відповідно, вивчення та впровадження міжнародних стандартів викладання та вивчення англійської мови професійного спрямування набуває особливої актуальності в контексті стратегічного розвитку та інтеграції до світової академічної спільноти вітчизняної галузі вищої освіти.

Аналіз наукових праць. Серед закордонних дослідників варто зазначити роботи, які вважаються світовою класикою з проблеми викладання англійської мови для професійного спілкування, на які спирається більша частина триваючих міжнародних досліджень: Т. Хатчінсона, А. Вотерса, Т. ДадліІвенса, М. Дж. Сент Джона, Л. Ентоні, П. Стревенса, Д. Карвера та інших.

Серед вітчизняних досліджень уваги заслуговують напрацювання М. Лєбєдєвої, О. Тимошенко, Г. Бакаєвої, О. Борисенко, С. Висоцької, С. Кострицької, І. Зуєнок, О. Швець, Н. Поперечної та інших.

Не зважаючи на достатню кількість грунтовних праць, присвячених проблемі викладання та вивчення англійської мови професійного спрямування питання вивчення та адаптації сучасного світового досвіду до вітчизняних реалій в контексті інтернаціоналізації вищої освіти потребує подальшої розробки.

Тож, метою представленого дослідження визначено: дослідити позицію експертів вищої школи Великобританії відносно проблеми викладання англійської мови професійного спрямування в контексті інтернаціоналізації вищої школи. Для досягнення мети потрібно виконати такі завдання:

1. Розглянути міжнародні вимоги до рівня володіння англійською мовою випускниками та викладачами ВНЗ.

2. Дослідити результати досліджень фахівців вищої школи Великобританії, спрямованих на визначення потенціалу підвищення стандартів викладання англійської мови професійного призначення на базі вітчизняних ВНЗ.

3. Визначити перспективи та шляхи імплементації успішного міжнародного досвіду в зазначеному контексті.

Виклад основного матеріалу. Рівні володіння англійською мовою професійного спілкування для студентів та викладачів ВНЗ базуються на Загальноєвропейських рекомендаціях з мовної освіти (CEFR) у такому конкретизованому вигляді [1] (див. табл. 1). Введення вищезазначених рівнів в процес викладання англійської мови професійного спілкування у вітчизняній вищій школі зумовлено необхідністю підвищення якості надання освітніх послуг шляхом забезпечення прозорого оцінювання, визнаного в міжнародному середовищі. Зокрема, визначення мінімального вступного рівня до вітчизняних ВНЗ базується на Законі України "Про вищу освіту", "Про загальну середню освіту", Порядку проведення зовнішнього незалежного оцінювання та моніторингу якості освіти, Порядку проведення зовнішнього незалежного оцінювання результатів, здобутих на основі повної загальної середньої освіти і, відповідно, передбачає володіння англійською мовою на рівні В1 [2].

Таблиия 1

Загальні рівні володіння мовою

\begin{tabular}{|l|l|}
\hline \multirow{2}{*}{ ЕЛЕМЕНТАРНИЙ КОРИСТУВАЧ } & А1 Інтродуктивний ("відкриття") \\
\cline { 2 - 2 } & А2 Середній ("Виживання") \\
\hline НЕЗАЛЕЖНИЙ КОРИСТУВАЧ & В1 Рубіжний \\
\hline
\end{tabular}




\begin{tabular}{|l|l|}
\hline \multirow{2}{*}{ ДОСВІДЧЕНИЙ КОРИСТУВАЧ } & В2 Просунутий \\
\cline { 2 - 2 } & С1 Автономний \\
\hline
\end{tabular}

Відповідно до рекомендацій Національної програми 3 англійської мови для професійного спілкування, розробленою командою українських фахівців разом з експертами Британської Ради, та рекомендованою Міністерством освіти і науки України до використання у вітчизняних ВН3, що здійснюють підготовку фахівців з різних спеціальностей, у випадку, коли рівень володіння англійською мовою абітурієнтом $є$ нижчим за вищевказані вимоги, що може мати місце з різних об'єктивних причин (наприклад, в середній школі викладалася інша іноземна мова), українські ВНЗ повинні пропонувати додаткові мовні курси з метою підвищення рівня до необхідного вступного мінімуму. Зазначена додаткова підготовка передбачає інтенсивний факультативний формат із виділенням більшої кількості аудиторних годин до початку опанування основного курсу англійської мови для професійного спілкування [3: 2].

Визначення цільового рівня володіння англійською мовою випускниками ВНЗ відповідно до міжнародної практики має базуватися на дескрипторах, запропонованих Загальноєвропейськими рекомендаціями 3 мовної освіти; державних вимогах до освітньо-кваліфікаційних характеристик випускників ВНЗ; конкретних посадових інструкціях, затверджених підприємствами та організаціями за профілем професійної діяльності здобувачів вищої освіти; результатах відповідних досліджень та опитувань фахівців, викладачів та студентів [3:3].

Як зазначається в Національній програмі з англійської мови для професійного спілкування, основним критерієм визначення необхідного рівня володіння англійською мовою $\epsilon$ реальні вимоги, що висуваються світовим ринком праці. Відповідні показники можна знайти в рекомендаціях міжнародної системи тестування англійської мови (IELTS), що передбачає існування спеціальностей, які вимагають більш або менш складної іншомовної поведінки [4: 5]. Відповідна градація, адаптована до затверджених рівнів вітчизняної вищої освіти та співвіднесена з відповідними рівнями володіння англійською мовою за CEFR, представлена в Національній програмі з англійської мови для професійного спілкування таким чином (див. табл. 2):

Таблиия 2

Міжнародно прийняті рівні володіння мовою для різних спеціальностей

\begin{tabular}{|c|c|c|c|c|}
\hline \multirow[b]{2}{*}{$\begin{array}{l}\text { Рівень } \\
\text { вищої } \\
\text { фсвіти } \\
\text { Рівні } \\
\text { IELTS }\end{array}$} & \multicolumn{2}{|c|}{ Магістерський } & \multicolumn{2}{|c|}{ Бакалаврський } \\
\hline & $\begin{array}{c}\text { Вимагається } \\
\text { більш складна } \\
\text { мовна поведінка }\end{array}$ & $\begin{array}{c}\text { Вимагається } \\
\text { менш складна } \\
\text { мовна поведінка }\end{array}$ & $\begin{array}{c}\text { Вимагається } \\
\text { більш складна } \\
\text { мовна поведінка }\end{array}$ & $\begin{array}{c}\text { Вимагається } \\
\text { менш складна } \\
\text { мовна поведінка }\end{array}$ \\
\hline $\begin{array}{c}7.5+ \\
(\mathrm{C} 2) \\
\end{array}$ & Прийнятний & Прийнятний & Прийнятний & Прийнятний \\
\hline $7.0(\mathrm{C} 1)$ & $\begin{array}{r}\text { Імовірно } \\
\text { прийнятний }\end{array}$ & Прий & Прийнятний & Прийг \\
\hline $\begin{array}{r}6.5 \\
(\mathrm{~B} 2+) \\
\end{array}$ & $\begin{array}{c}\text { Потребує } \\
\text { вивчення мови }\end{array}$ & $\begin{array}{r}\text { Імовірно } \\
\text { прийнятний }\end{array}$ & Прийнятний & Прийнятний \\
\hline $6.0(\mathrm{~B} 2)$ & $\begin{array}{c}\text { Потребує } \\
\text { вивчення мови }\end{array}$ & $\begin{array}{c}\text { Потребує } \\
\text { вивчення мови }\end{array}$ & $\begin{array}{r}\text { Імовірно } \\
\text { прийнятний }\end{array}$ & Прийнятний \\
\hline $5.5(\mathrm{~B} 2)$ & $\begin{array}{c}\text { Потребує } \\
\text { вивчення мови }\end{array}$ & $\begin{array}{c}\text { Потребує } \\
\text { вивчення мови }\end{array}$ & $\begin{array}{c}\text { Потребує } \\
\text { вивчення мови }\end{array}$ & $\begin{array}{r}\text { Імовірно } \\
\text { прийнятний }\end{array}$ \\
\hline
\end{tabular}

Серед спеціальностей, що передбачають більш складну мовну поведінку (назви адаптовано до актуального переліку, за яким здійснюється підготовка здобувачів вищої освіти в Україні [5]) можна зазначити Медицину; Право; Підприємництво, торгівлю та біржову діяльність; Туризм; Журналістику; Філологію; Інформаційну, бібліотечну та архівну справу; Авіаційний транспорт, тощо. До напрямів, що вимагають менш високої іншомовної підготовки віднесено Комп'ютерні науки; Інформаційні системи та технології; Математику; Телекомунікації та радіотехніку; Агрономію; Технологію виробництва і переробки продукції тваринництва; Харчові технології; Пожежну безпеку, тощо [4].

Для бакалаврів відповідна програма констатує мінімальний прийнятний рівень володіння мовою - В2 (Незалежний користувач). Під час випускного кваліфікаційного іспиту студент має продемонструвати здатність ефективно використовувати англійську мову у професійному середовищі. А саме: обговорювати навчальні та пов'язані 3 професійною діяльністю питання (з метою досягнення порозуміння із співрозмовником); представляти публічні виступи 3 широкого кола професійноорієнтованих питань (застосовуючи відповідні засоби вербальної комунікації, адекватні форми ведення дискусії та дебатів); знаходити необхідну текстову, графічну, аудіо та відеоінформацію в англомовних матеріалах (друкованих та електронних) професійного спрямування (користуючись відповідними 
пошуковими методами та термінологією); аналізувати англомовні джерела інформації (з метою отримання даних, необхідних для вирішення професійних завдань та прийняття рішень); складати англомовні тексти та документи професійно-орієнтованого характеру; писати ділові листи професійноорієнтованого спрямування (демонструючи розуміння міжкультурних відмінностей та професійну обізнаність); перекладати англомовні тексти професійного спрямування рідною мовою (користуючись друкованими або електронними двомовними термінологічними словниками, програмним забезпеченням для перекладу) [3: 3].

Природнім $є$ той факт, що разом з професійним зростанням здобувача вищої освіти підвищуються вимоги до рівня володіння іноземною мовою в контексті того середовища, де він планує працювати або навчатися далі. Зокрема, для магістрів, майбутня професійна діяльність яких передбачає менш складну мовну поведінку, визнається рівень В2+ як імовірно достатній для здійснення професійних обов'язків. Для спеціальностей, що вимагають більш складної мовної поведінки рівень С1 зазначено як мінімально прийнятний. 3 метою здійснення ефективної комунікації в академічному та професійному середовищі під час проходження програми підготовки здобувачами вищої освіти рівень В2 визнано як цілком достатній (тобто, той рівень, який очікується в результаті здобуття ступеня бакалавру) [3: 4].

У вищезазначеному контексті, доцільним, на наш погляд, буде, також, розглянути вимоги до рівня володіння англійською мовою викладачами ВНЗ. Зокрема, в ході дослідження проблеми інтернаціоналізації університетів в розрізі англійської мови британські експерти дійшли висновку про те, що станом на сьогодні немає окремого встановленого стандарту володіння мовою для університетських викладачів англійської мови в Україні. Загальною вимогою для науково-викладацького складу $\epsilon$ підтвердження рівня В2, що уможливлює проходження відповідної атестації. Міжнародні фахівці ж радять визнати рівень С1 відповідно до Загальноєвропейських рекомендацій 3 мовної освіти в якості кваліфікаційної вимоги для зазначеної групи викладацького складу вітчизняної вищої школи (викладачів курсів англійської мови загального та професійного спрямування) [6: 42]. Доцільність визначення відповідного рівня зумовлена тим фактом, що мінімально прийнятним рівнем для викладачів англійської мови загальноосвітніх шкіл, встановленим Міністерством освіти і науки України, визначено С1 [6: 19]. Тож, логічним є те, що рівень викладача вищої школи не має бути нижчим за кваліфікацію викладача середньої школи [6: 36].

Вивчаючи результати дослідження фахівців вищої школи Великобританії щодо визначення потенціалу підвищення стандартів викладання англійської мови професійного призначення на базі вітчизняних ВНЗ, доцільно, з нашої точки зору, в першу чергу, розглянути наявні проблеми, які було діагностовано британськими експертами протягом 2014-2016 років в межах проектного дослідження "Англійська мова для університетів" серед 15 вітчизняних ВНЗ. Дослідження охопило як елітні заклади 3 високим рейтингом, так і нижчі за статусом. Як відзначають експерти, отримані результати $є$ на диво послідовними від одного університету до іншого [6: 23]. Тож, представлені висновки, безперечно, мають значну цінність для всіх вищих навчальних закладів України в контексті удосконалення системи викладання англійської мови професійного спрямування.

На загальнодержавному стратегічному рівні експерти визначають чітку потребу модернізувати та інтернаціоналізувати університети по всій Украӥні в контексті впровадження міжнародних стандартів викладання англійської мови. На думку представників міжнародної спільноти рівень автономії університетів та межа їх відповідальності не є достатньо визначеними, в першу чергу, самим Міністерством. Зокрема, мова йде про укладання відповідної навчальної програми, створення якісних англомовних навчально-методичних матеріалів та визначення кількості необхідних контактних годин (часовий проміжок, протягом якого студент отримує активні інструкції, та який розглядається як частина навчального курсу [7]) для опанування певного рівня англійської мови відповідно до Загальноєвропейських рекомендацій з мовної освіти. За спостереженнями британських фахівців, це, наразі, призводить до плутанини та нерішучості, а іноді, слугує вигідним виправдання "зручної бездіяльності" [6: 91].

Як наслідок, відповідні положення Національної програми не були ефективно поширені. Як йдеться у звіті британських експертів, про них або зовсім не знають, або ж вони ігноруються [6: 92]. Зокрема, документ містить важливі рекомендації стосовно кількості контактних годин та необхідних рівнів володіння англійською мовою для основних груп учасників навчально-виховного процесу у вищій школі відповідно до міжнародних стандартів [3]. Тож, є нагальна необхідність звернути увагу на наявну проблему, пов'язану з національними стандартами та навчальними програмами.

За результатами дослідження британських експертів зафіксовано недостатню відповідність модулів начальних програм та кредитів реальним вимогам Болонського процесу, до якого Україна офіційно приєдналася в 2005 р. Також, мова йде про дуже обмежене застосування системи контролю якості. Як зауважують експерти, мало хто з керівництва університетів, які вони консультували, були обізнані про всі очікувані наслідки приєднання до Болонського процесу [6: 92]. В зазначеному контексті, вивчення та 
дотримання міжнародно-узгоджених вимог в освітній галузі визначено в якості одного з пріоритетів для України.

Також, британськими експертами окреслено проблему значної відмінності підходів серед вітчизняних університетів до організачії викладання англійської мови. Як зазначається у звіті, часто викладання англійської мови здійснюють декілька кафедр, які застосовують відмінні підходи до створення навчальних програм та методики. Окрім цього, різні факультети мають різні підходи щодо визначення кількості років та контактних годин, відведених на вивчення англійської мови. На окремих факультетах студенти можуть вивчати англійську мову довше або коротше [6:93]. Тож, міжнародні експерти вбачають доцільним поставити питання удосконалення функціонування відповідних кафедр у зазначеному контексті.

Вимоги до рівня володіння англійською мовою випускниками українських ВНЗ, узгоджених Міністерством освіти і науки України, з врахуванням наявної ситуації, яка має місце у вітчизняній системі вищої освіти, британські експерти визнають як нереалістичні та занадто високі для деяких спеціальностей [6: 93]. Логічним продовженням означено неможливість українськими ВНЗ надати реальну гарантію якості англомовної підготовки відповідно до вимог Болонської угоди. Крім того, результати дослідження британських експертів засвідчили низький рівень якості тестів 3 англійської мови, а також, нагальну потребу привести випускні іспити з англійської мови у точну відповідність до шкали Загальноєвропейських рекомендацій 3 мовної освіти. Як із сумом констатують міжнародні фахівці, наразі, Міністерство, роботодавці та українське суспільство в цілому не мають надійних способів дізнатися про реальну якість підготовки з англійської мови у вітчизняних ВНЗ.

Певне занепокоєння міжнародних фахівців викликає наявний рівень володіння англійською мовою серед викладачів англійською мовою вітчизняних ВНЗ. Як зазначається в результатах дослідження, переважно викладачі англійської мови в університетах володіють мовою на рівні В2 / С1. Але мало хто демонструє рівень С1 за всіма показниками. А певна частина викладачів не досягає навіть мінімального загального рівня [6: 108]. На думку експертів це, не в останню чергу, пов'язано з ролями та обов'язками викладачів англійської мови в українських університетах. Зокрема, позицію міжнародних експертів в цьому контексті можна відобразити такою цитатою зі звіту: "Ступінь доктора філософії ще нікому не допомогла стати кращим викладачем" [6:95]. Мова йде про звільнення викладацького складу від обов'язкового проведення наукової роботи на користь професійного розвитку: удосконалення педагогічних умінь та підвищення рівня володіння англійською мовою.

Підсумовуючи висновки, британські експерти констатують, що маючи високі освітньо-кваліфікаційні рівні та наукові ступені, більшість вітчизняних викладачів ВНЗ професійно віддалена від сучасних тенденцій і має обмежену підготовку з викладання англійської мови професійного спрямування або не має іiі взагалі. Вивчаючи питання політики українських ВНЗ в контексті англійської мови британські експерти констатують неоднозначне ставлення до необхідності здійснення безперервного професійного розвитку серед викладачів англійської мови. Хоча деякі розглядають таку перспективу з ентузіазмом, більшість заперечує потребу у подальшому професійному вдосконаленні та надають перевагу підвищенню освітньої кваліфікації із відповідною підготовкою публікацій, необхідних для подальшої атестації.

В зазначеному контексті міжнародні експерти не заперечують високу цінність потреби і можливостей серед викладачів англійської мови здійснювати дослідницьку діяльність. Але, у той же час, британські фахівці відзначають невідповідність певної частини затвердженої тематики професійним інтересам викладачів англійської мови. На думку експертів, це зумовлено тим, що часом тему визначає науковий керівник, а не виконавець дослідження. Як факт, міжнародні дослідники констатують, що в Украӥні практично невідомо, що англійська мова професійного спрямування - загальновизнана галузь досліджень iз власною літературою та міжнародними науковими журналами, які рецензують спеціалісти у цій галузі [6: 99].

Логічним продовженням окресленого контексту є необхідність розробки більи сучасних та гнучких навчальних планів з англійської мови на університетському рівні. Відповідні положення мають відображати пріоритетність англійської як мови міжнародного спілкування; бути націленими на задоволення академічних та професійних потреб студентів; базуватися на міжнародних стандартах (зокрема, Загальноєвропейських рекомендаціях з мовної освіти стосовно визначення рівнів володіння мовою, змісту навчальної програми, тестів та інших інструментів перевірки навчальних досягнень).

У тісному зв'язку з нормативною базою перебуває питання якості навчально-методичних матеріалів для викладання англійської мови професійного спрямування. Як зазначають експерти, хоча в деяких університетах вже є доступними навчальні матеріали міжнародного рівня, у більшості закладів все ще виникає постійна потреба створювати "методички власного виробництва". Ці розробки, переважно, передбачають роботу з граматикою та перекладом без застосування сучасних підходів. На думку британських фахівців, у порівнянні з моделлю викладання іноземних мов у Радянському Союзі 50-х років, зазначені матеріали зазнали мало змін [6: 95]. 
Узагальнюючи результати діагностичного дослідження британських експертів щодо наявної ситуації в контексті викладання англійської мови професійного спрямування у вітчизняних ВНЗ, головною проблемою визначено брак практичної підготовки викладацького складу, що відображається через: відсутність сучасної методики. Багато викладачів англійської мови погано розуміють або не визнають взагалі той факт, що існує широке різноманіття методик та підходів, які застосовуються у схожих умовах по всьому світу; неефективне викладання для груп зі змішаним рівнем мовної підготовки. Багато викладачів скаржаться, що вони не можуть добре впоратися з групою зі змішаними рівнями; брак навичок викладання англійської мови професійного спрямування, англійської мови для академічних цілей, вмінь ефективного навчання. Відповідні технології невідомі широкому українському загалу та, відповідно, не практикуються; невідповідність вітчизняних підходів до розробки навчально-методичних матеріалів міжнародній практиці. Зокрема, при роботі 3 текстами потрібно зосередитися на аналізі дискурсу та жанру як основи для подальшої роботи; неякісне та неефективне оцінювання. Потрібно покращити розуміння того, як оцінювати прогрес та навчальні досягнення здобувачів вищої освіти; як діють стандарти Загальноєвропейських рекомендацій з мовної освіти; як працює тестування на визначення рівня володіння англійською мовою.

Останнім, але не менш важливим питанням, що потребує вирішення, британськими експертами було визначено кількість контактних годин, відведених на вивчення англійської мови у вітчизняних ВНЗ. Як зазначається у звіті, це - скарга номер один серед викладачів усіх університетів, які розчаровані недостатньою кількістю годин. Міжнародні експерти вбачають сутність проблеми у тому, що збільшення відповідного обсягу залежить від вказівки вищого керівництва університету; в багатьох випадках вивчення англійської мови взагалі припиняється після другого, третього або четвертого семестру бакалаврату. Тож, на думку британських фахівців, поточна ситуація унеможливлює досягнення цільового рівня.

3 іншого боку, хоча у вище окреслених умовах викладачам складно допомогти студентам підняти рівень володіння англійською мовою, експерти не побачили достатньої обізнаності викладацького складу вітчизняних ВНЗ щодо можливостей розвитку іншомовної компетентності студентів за допомогою навичок самостійної роботи, покликаних компенсувати нестачу контактних годин [6: 101].

Разом із окресленням, з нашої точки зору, цілком об'єктивним, наявного становища у вітчизняних ВН3 в контексті викладання англійської мови професійного спрямування, експерти вищої освіти Великобританії пропонують скористатися успішним міжнародним досвідом у зазначеному контексті 3 метою підвищення відповідних стандартів та забезпечення сталого розвитку вищої освіти України. Зокрема, рекомендовано:

- $\quad$ визнати важливість англійської мови для наукових установ, проведення досліджень; включити популяризацію викладання та вивчення англійської мови до національної стратегії;

- модернізувати та перевидати Програму з англійської мови для професійного спілкування, розроблену командою Міністерства освіти і науки України у 2005 році, додавши рекомендації щодо можливостей іiї впровадження в університетах;

- $\quad$ надіслати (повторно) рекомендащіï Міністерства освіти і науки України щодо контактних годин, необхідних для досягнення відповідних рівнів володіння англійською мовою за шкалою Загальноєвропейських рекомендацій з мовної освіти до вітчизняних ВНЗ;

- $\quad$ забезпечити відповідну підготовку персоналу та більш ефективний документообіг в контексті узгодження внутрішніх стандартів з вимогами Болонського процесу;

- організувати (за можливістю) консолідоване викладання англійської мови професійного спрямування однією кафедрою, застосовувати єдиний підхід до створення навчальних програм на всіх факультетах, забезпечити достатню кількість годин для досягнення відповідних рівнів володіння англійською мовою відповідно до CEFR;

- $\quad$ створити команди на основі кафедр іноземних мов із розподілом відповідних обов'язків щодо розробки навчальних програм, підбору та створення навчально-методичних матеріалів, оцінювання, забезпечення контролю якості, атестації та професійного розвитку колективу, тощо. Проводити ротацію відповідних обов'язків кожні три роки з метою отримання викладачами досвіду та підготовки в усіх сферах;

- встановити вимоги до рівня володіння англійською мовою випускниками ВНЗ у прямій відповідності до Загальноєвропейських рекомендацій 3 мовної освіти (С1 - для спеціальностей 3 високими вимогами до іншомовної поведінки, В2 - для спеціальностей з менш високими вимогами до іншомовної поведінки);

- $\quad$ додати помітку в документи про освіту із зазначенням рівня англійської мови, якого досяг випускник (виділити певний час для реалізації зазначеної ідеї);

- $\quad$ провести підготовку викладачів англійської мови щодо сучасних чинних процедур тестування й оцінки рівня володіння англійською мовою; 
- ввести вимоги до рівня володіння англійською мовою викладачами ВНЗ як критерію призначення чи переведення на вищу посаду у такій відповідності: С1 - для викладачів англійської мови, В2 - для викладачів фахових дисциплін;

- $\quad$ провести підготовку викладацького складу до застосування сучасних підходів 3 метою створення навчальних програм;

- $\quad$ відійти від виготовлення вузькоспеціалізованих "методичок" на користь матеріалів, розроблених міжнародними видавцями;

- $\quad$ в одному 3 університетів України створити департамент 3 централізованої розробки підручників з англійської мови професійного спрямування, провести відповідну підготовку та створити команду спеціалістів-авторів;

- переглянути обов'язки викладачів англійської мови в університетах, звільнити їх від обов'язкового проведення досліджень та виготовлення публікацій для обмеженої аудиторії задля проведення атестації, на користь зосередження на викладанні;

- вбудувати Загальноєвропейські рекомендації з мовної освіти в усі аспекти викладання англійської мови професійного спрямування: розробку програми, визначення мети та очікуваних результатів навчання, тощо;

- $\quad$ визначити пріоритетом дослідницької діяльності для викладачів англійської мови ті теми, які пов’язані з викладацькою практикою, а не туманними галузями літератури та лінгвістики;

- $\quad$ озробити та впровадити політику безперервного професійного розвитку для викладачів англійської мови у кожному університеті з регулярним підвищенням методичної кваліфікації та забезпеченням можливості здійснювати професійні візити до інших країн;

- $\quad$ фокусувати професійну підготовку викладачів англійської мови на практичних питаннях викладання англійської мови професійного спрямування в університеті;

- збільшити кількість контактних годин для досягнення відповідних рівнів володіння англійською мовою у відповідність до рекомендацій Міністерства освіти і науки України;

- $\quad$ провести підготовку для викладачів щодо розвитку стратегій автономного навчання серед студентів [6].

Зважаючи на акцент, який надається міжнародними експертами забезпеченню відповідного навчання та підготовки викладацького складу університетів, в межах реалізації плану дій Східноукраїнського національного університету імені Володимира Даля на 2017-2018 навчальний рік було заплановано та проведено низку заходів з розповсюдження успішного досвіду у зазначеному контексті за результатами участі викладацького складу в освітніх заходах Британської Ради в Україні. Зокрема, в межах участі СНУ ім. В. Даля в проекті "Англійська мова для університетів" викладачами кафедри іноземних мов та професійної комунікації було проведено англомовний семінар "Англійська мова для нефілологічних спеціальностей". Зустріч було присвячено питанням методики викладання дисципліни "Англійська мова професійного спрямування" та спеціальних предметів англійською мовою. Серед присутніх були викладачі іноземних мов, фахівці, які вже здійснюють педагогічну діяльність або планують розпочати викладання фахових дисциплін англійською мовою, а також, студенти, які бажають підвищити рівень англійської мови та реалізувати власний потенціал в міжнародному контексті.

Серед актуальних питань, що отримали живий відгук аудиторії, було висвітлено проблему практичного застосування сучасних підходів до викладання іноземних мов для студентів нефілологічних спеціальностей в умовах переміщеного ВНЗ; окреслено вимоги до рівня володіння англійською мовою студентами бакалаврату та магістратури, що нададуть випускникам ширші можливості для самореалізації на міжнародному ринку праці, а також, потенційні шляхи інтенсифікації вивчення іноземних мов; охарактеризовано особливості застосування мотиваційних технологій в контексті вивчення іноземних мов студентами нелінгвістичних спеціальностей та навчання фаховим предметам англійською мовою 3 урахування викликів сьогодення; запропоновано практичні рекомендації для фахівців, які застосовують іноземну мову у вищезазначеному контексті, щодо забезпечення відповідності вимогам, урахування особливостей підбору автентичних навчальних матеріалів та створення ефективних завдань для студентів.

В межах підсумкового виступу було визначено завдання щодо удосконалення ефективної взаємодії викладачів та здобувачів вищої освіти, зокрема, через застосування сучасних методів організації навчальної роботи 3 використанням іноземної мови в якості предмета вивчення та інструменту для оволодіння фаховими компетенціями. Важливо зазначити, що у змісті заходу знайшов відображення досвід британських експертів в галузі вищої освіти, з яким команда викладачів СНУ ім. В. Даля мала змогу ознайомитися під час Літньої школи професійного розвитку в липні 2017 року в Києві [8].

Інший захід, який мав на меті розповсюдження успішного міжнародного досвіду у зазначеному контексті, та був спрямований на зміцнення взаємодії між вітчизняними освітніми закладами та розвиток освітнього потенціалу східного регіону України, був реалізований викладачами кафедри іноземних мов та професійної комунікації в формі англомовного науково-методичного круглого столу за темою 
"Планування занять 3 англійської мови для професійного спілкування". В межах заходу було представлено доповіді випускників Літньої школи професійного розвитку викладачів англійської мови 2017, організованої Британською Радою в Україні, стосовно сучасних підходів до вивчення, викладання та оцінювання рівня володіння англійською мовою на основі кращих практик Великобританії. Також, відбулася англомовна дискусія в контексті вищезазначеної тематики.

Серед присутніх були викладачі англійської мови загальноосвітніх шкіл, гімназії, колегіуму, ліцею, хіміко-механічного технікуму м. Сєверодонецька, а також, Борівського навчально-виховного комплексу. Серед актуальних питань, навколо яких відбулася дискусія, можна відзначити проблему ролей викладача англійської мови в класі, врахування особистого стилю навчання студентів, підбору доцільних режимів взаємодії 3 аудиторією, технології ефективного планування занять із визначенням ключових компонентів. Також, було окреслено перспективи використання міжнародної системи тестування англійської мови в контексті здійснення сучасної іншомовної підготовки здобувачів освіти [9].

Отже, в результаті дослідження позиції експертів вищої школи Великобританії відносно проблеми викладання англійської мови професійного спрямування в контексті інтернаціоналізації вітчизняної галузі вищої освіти:

1. З'ясовано, що рівні володіння англійською мовою професійного спрямування у вітчизняних ВНЗ співвідносяться 3 загальними положеннями Загальноєвропейських рекомендацій 3 мовної освіти. Зокрема, мінімальний вступний рівень до закладів вищої освіти визначено як В1, а цільовий рівень володіння англійською мовою для бакалаврату $є$ В2, в той час, як за результатами опанування магістратури очікується досягнення рівнів В2+ або С1 в залежності від спеціальності, що передбачає більш або менш складну мовну поведінку. Сдиним атестаційним стандартом для науково-педагогічного складу вітчизняних ВНЗ є підтвердження рівня В2.

2. Схарактеризовано такі проблеми вітчизняної вищої школи в контексті викладання англійської мови професійного спрямування за результатами дослідження Британських експертів: нечітке визначення рівня повноважень та відповідальності університетів в окресленому контексті; недотримання рекомендацій Національної програми 3 англійської мови для професійного спілкування; недостатня обізнаність щодо очікуваних результатів приєднання до Болонського процесу; відсутність єдиного узгодженого підходу до викладання англійської мови професійного спрямування як серед ВНЗ України, так і всередині окремо розглянутих установ; нереалістичні очікування щодо рівня володіння англійською мовою випускниками українських ВНЗ за деякими напрямами підготовки; відсутність гарантії якості англомовної підготовки у вітчизняній вищій школі; необхідність підвищення рівня професійної компетентності викладачів англійської мови в контексті володіння мовою, методичної підготовки та обізнаності щодо результатів актуальних наукових досліджень в галузі викладання англійської мови професійного спрямування, недостатня якість англомовних навчально-методичних матеріалів та брак практичної підготовки викладацького складу вітчизняних ВНЗ.

3. Окреслено перспективи підвищення стандартів викладання англійської мови професійного спрямування на основі успішного міжнародного досвіду, зокрема, через: розробку стратегії популяризації вивчення англійської мови на базі вищих навчальних закладів для різних цільових аудиторій (студентів, викладачів, науковців, тощо); удосконалення системи викладання англійської мови (узгодження та дотримання єдиного підходу, збільшення кількості контактних годин, створення викладацьких команд на базі кафедр іноземних мов, тощо); встановлення вимог до рівнів володіння англійською мовою відповідно до міжнародної практики та реальної ситуації, що має місце в країні; забезпечення відповідної підготовки та безперервного професійного розвитку викладачів англійської мови в мовному, методичному та науковому аспектах.

4. Визначено доцільність вивчення та розповсюдження успішного досвіду вищої школи Великобританії в зазначеному контексті, зокрема, через участь в освітніх міжнародних проектах та організацію подальшої дисемінації на базі вітчизняних ВНЗ.

Перспективи подальших досліджень. Логічне продовження представленого дослідження вбачаємо в дослідженні міжнародних стандартів та систем організації тестування рівня володіння англійською мовою відповідно до Загальноєвропейських рекомендацій з мовної освіти.

\section{СПИСОК ВИКОРИСТАНИХ ДЖЕРЕЛ ТА ЛІТЕРАТУРИ}

1. Common European Framework of Reference for Languages: Learning, Teaching, Assessment (CEFR) [Електронний pecypc] : Council of Europe 2001. - Режим доступу: https://www.coe.int/en/web/commoneuropean-framework-reference-languages.

2. Деякі питання проведення в 2018 році зовнішнього незалежного оцінювання результатів навчання, здобутих на основі повної загальної середньої освіти [Електронний ресурс] : Наказ МОН № 1103 від 31.07.2017. Режим доступу : http://zakon2.rada.gov.ua/laws/show/z1014-17.

3. Програма з англійської мови для професійного спілкування / [Г. Є. Бакаєва, О. А. Борисенко, І. І. Зуєнок, В. О. Іваніщева， Л. Й. Клименко, Т. І. Козимирська, С. І. Кострицька, Т. І. Скрипник, Н. Ю. Тодорова, А. О. Ходцева]. - Київ : Ленсвіт, 2005. - 119 с. 
4. IELTS [Електронний pecypc]: Handbook $2007 . \quad$ Режим https://ru.scribd.com/document/4612729/IELTS-Handbook-2007.

5. Про затвердження переліку галузей знань і спеціальностей, за якими здійснюється підготовка здобувачів вищої освіти [Електронний ресурс] : Постанова Кабінету Міністрів України №266 від 29.04.2015. - Режим доступу : http://zakon3.rada.gov.ua/laws/show/266-2015-\%D0\%BF/paran11\#n11.

6. Болайто Р. Інтернаціоналізація українських університетів у розрізі англійської мови : проект "Англійська мова для університетів" / Р. Болайто, Р. Вест. - К. : Видавництво "Сталь", 2017. - 154 с.

7. English Oxford Living Dictionaries [Електронний ресурс] : contact hours definition. - Режим доступу: https://en.oxforddictionaries.com/definition/contact_hours.

8. Викладачі кафедри іноземних мов поділилися освітнім досвідом Великобританії [Електронний ресурс] : Новини СНУ ім. В. Даля. - Режим доступу : https://snu.edu.ua/?p=15830.

9. Викладачі кафедри іноземних мов запросили в гості освітян Сєверодонецька [Електронний ресурс] : Новини СНУ ім. В. Даля. - Режим доступу : https://snu.edu.ua/?p=16966.

\section{REFERENCES (TRANSLATED \& TRANSLITERATED)}

1. Common European Framework of Reference for Languages : Learning, Teaching, Assessment (CEFR) [Elektronnyi resurs] : Council of Europe 2001. - Rezhym dostupu : https://www.coe.int/en/web/common-european-frameworkreference-languages.

2. Deiaki pytannia provedennia v 2018 rotsi zovnishnioho nezalezhnoho ociniuvannia rezul'tativ navchannia, zdobutykh na osnovi povnoi zahal'noi serednioi osvity [Elektronnyi resurs] : Nakaz № 1103 vid 31.07.2017 [Some Issues Concerning External Independent Evaluation of the Secondary School Learning Outcomes in 2018 : MSE Decree № 1103 Dated 31.07.2017]. - Rezhym dostupu : http://zakon2.rada.gov.ua/laws/show/z1014-17.

3. Prohrama $\mathrm{z}$ anhliis'koi movy dlia profesiinoho spilkuvannia [English for Specific Purposes (ESP): National Curriculum for Universities] / G. Bakaieva, O. Borysenko, V. Ivanischeva, A. Khodtseva, L. Klymenko, S. Kostrytska, T. Kozymyrska, T. Skrypnyk, N. Todorova, I. Zuienok. - Kyiv : Lensvit, 2005. - 119 s.

4. IELTS [Elektronnyi resurs] : Handbook 2007. - Rezhym dostupu : https://ru.scribd.com/document/4612729/IELTSHandbook-2007.

5. Pro zatverdzhennia pereliku haluzei znan' i spetsial'nostei, za yakymy zdiisniuietsia pidhotovka zdobuvachiv vyshhoi osvity [Elektronnyi resurs] : Postanova Kabinetu Ministriv Ukrayiny № 266 vid 29.04.2015 [About Approval of the Expertise Areas and Specialisms List for Training Higher Education Applicants. Ukrainian Cabinet of Ministers : Resolution №266 Dated 29.04.2015]. - Rezhym dostupu : http://zakon3.rada.gov.ua/laws/show/2662015-\%D0\%BF/paran11\#n11.

6. Bolitho R. The Internationalisation of Ukrainian Universities : the English Language Dimention / R. Bolitho, R. West. - Kyiv : Stal, 2017. - 134 pp.

7. English Oxford Living Dictionaries [Elektronnyi resurs] : Contact Hours Definition. - Rezhym dostupu : https://en.oxforddictionaries.com/definition/contact hours.

8. Vykladachi kafedry inozemnykh mov podilylysia osvitnim dosvidom Velykobrytanii [Elektronnyi resurs] : novyny SNU imeni V. Dalia [Teaching Staff of the Foreign Languages and Professional Communication Department Have Shared the UK Educational Experience : VDEUNU News]. - Rezhym dostupu : https://snu.edu.ua/?p=15830.

9. Vykladachi kafedry inozemnykh mov zaprosyly v hosti osvitian Sievierodonetska [Elektronnyi resurs] : novyny SNU im. V Dalia [Teaching Staff of the Foreign Languages and Professional Communication Department Welcomed Educators from Severodonetsk : VDEUNU News]. - Rezhym dostupu : https://snu.edu.ua/?p=16966.

\section{Модестова Т. В. Интернационализация высиего образования в контексте преподавания английского языка профессионального направления: опыт Великобритании.}

В статье рассмотрена проблема интернаџионализации высшего образования в контексте преподавания английского языка профессионального направления. Исследована позиция экспертов высшей школь

Великобритании касательно перспектив повышения стандартов преподавания английского языка для профессионального общения на базе украинских ВУЗов. Определены существующие проблемы и потенциальные пути интернационализации высшей школы в указанно контексте.

Ключевые слова: интернационализация, высшее образование Великобритании, английский язык профессионального направления, Общеевропейские рекомендации по языковому образованию, международные стандарты преподавания и изучения английского языка.

\section{Modestova T. V. Internationalisation of Higher Education through Teaching English for Specific Purposes: the UK Experience.}

The problem of the higher education internationalization through teaching English for specific purposes is considered in the article. The relevance of English language competence in the professional context has been underlined as a key point of the represented study. The necessity to provide a sufficient competitive level for Ukrainian graduates through improving correspondent English language training has been considered. The research is based on studying HE British experts' reports and current scientific publications presented by international researchers focused on internationalization challenges and prospective for Ukrainian universities 
in English language dimension. Analysis of international English teaching, learning and assessment standards, and approaches, as well as the UK experts' research outcomes has been used as a key method for the represented article. The correspondence between the CEFR basic levels and ESP proficiency has been identified. The current challenges in the context of internationalization of Ukrainian Universities have been characterized. The perspective for further improvement of ESP teaching and learning standards at Ukrainian universities has been found. The relevance of studying and adaptation of the UK HE successful practice has been highlighted. The participation of Ukrainian higher education establishments in international research and educational projects, as well as dissemination of successful experience, taken through international interaction, around Ukraine are identified as potential ways for internationalization of Ukrainian universities in the English language dimension.

Key words: internationalization, the UK higher education, English for specific purposes, Common European framework of Reference for Languages: Learning, Teaching, Assessment, English teaching and learning standards. 